\title{
South Tasman Sea alkenone palaeothermometry over the last four glacial/interglacial cycles
}

\author{
C. Pelejero ${ }^{\text {a,b,c,* }}$, E. Calvo ${ }^{\text {a,b,c }}$, T.T. Barrows ${ }^{\text {d }}$, G.A. Logan ${ }^{\text {b }}$, P. De Deckker ${ }^{\text {e }}$ \\ ${ }^{a}$ Research School of Earth Sciences, The Australian National University, Canberra, ACT 0200, Australia \\ ${ }^{\mathrm{b}}$ Petroleum and Marine Division, Geoscience Australia, GPO Box 378, Canberra, ACT 2601, Australia \\ ${ }^{\mathrm{c}}$ Institut de Ciències del Mar, CMIMA-CSIC, Pg. Marítim de la Barceloneta, 37-49, 08003 Barcelona, Catalonia, Spain \\ ${ }^{\mathrm{d}}$ Research School of Physical Sciences and Engineering, The Australian National University, Canberra, ACT, 0200 Australia \\ ${ }^{\mathrm{e}}$ Department of Earth and Marine Sciences, The Australian National University, Canberra ACT 0200, Australia
}

Received 1 June 2005; received in revised form 24 February 2006; accepted 9 April 2006

\begin{abstract}
Alkenone palaeothermometry has demonstrated a wide spatial and temporal applicability for the reconstruction of sea-surface temperatures (SST). Some oceanic realms, however, remain poorly studied. We document $U_{37}^{K^{\prime}}$ index data for two sediment cores retrieved from the South Tasman Sea, one west of New Zealand (SO136-GC3) and the other southeast of Tasmania (FR1/94-GC3), extending back $280 \mathrm{kyr}$ BP for the former and $460 \mathrm{kyr}$ BP for the latter. High climatic sensitivity on orbital time scales is observed at both locations, particularly west of New Zealand, where typical glacial/interglacial SST amplitudes always span more than $7^{\circ} \mathrm{C}$. Southeast of Tasmania, SST amplitudes are lower in amplitude $\left(4.3\right.$ to $\left.6.9{ }^{\circ} \mathrm{C}\right)$ with the exception of Termination IV, which involved a SST change over $8{ }^{\circ} \mathrm{C}$. The evolution of maximum glacial cooling through time is different at each location. Offshore New Zealand, maximum cooling during glacial stages increases with time, whereas south of Tasmania maximum cooling decreases with time. In addition, our data suggest heterogeneity in the spatial expression of SST during the penultimate and last glacial stages. These glacial periods are recorded differently in both areas, with Marine Isotopic Stage 6 being warmer than Marine Isotopic Stage 2 west of New Zealand, but slightly colder southeast of Tasmania. The area southwest of New Zealand appears susceptible to expansions and contractions of the Western Pacific Warm Pool and/or meridional migrations and changes in intensity of currents associated with the Tasman Front. The region southeast of Tasmania seems more sensitive to thermal changes as seen at high southern latitudes.
\end{abstract}

(c) 2006 Elsevier B.V. All rights reserved.

Keywords: SST; South Pacific Ocean; molecular biomarker; late Pleistocene; $U_{37}^{K^{\prime}}$; Marine Isotopic Stage 11

\footnotetext{
* Corresponding author. Institut de Ciències del Mar, CMIMACSIC, Pg. Marítim de la Barceloneta, 37-49, 08003 Barcelona, Catalonia, Spain. Tel.: +34 93 2309500; fax: +34 932309555.

E-mail address: pelejero@cmima.csic.es (C. Pelejero).
}

\section{Introduction}

Over the past few decades, the study of deep-sea sediments has revolutionised our understanding of global climate change, demonstrating the crucial and active role played by the oceans. New technologies and advances in analytical chemistry have made possible the development of a variety of proxies which form the 
basis of palaeoceanography, a fertile scientific discipline in clear expansion. Since the early stages of palaeoceanographic studies, much effort has been put into reconstructing sea-surface temperatures (SST), arguably the most important parameter for the Earth's climate system. Amongst available SST proxies, the alkenone palaeothermometer developed in the late eighties (see the first definition of the $U_{37}^{K}$ index in Brassell et al., 1986) has demonstrated spatial and temporal applicability and a significant robustness. As opposed to some other SST proxies (e.g. foraminifera $\mathrm{Mg} / \mathrm{Ca}$ and coral $\mathrm{Sr} / \mathrm{Ca}$ ) where global calibrations are still difficult to conceive, alkenone palaeothermometry can be applied today to derive SSTs from most oceanic basins through a single and global transfer equation (Müller et al., 1998).

However, after one and a half decades of $U_{37}^{K}$ index reconstructions, there are still important oceanic areas for which data using this index have not been generated, particularly from the South Pacific Ocean. In this paper, we document new alkenone SST estimates for the South Tasman Sea. The studied records are under the influence of warm, saline, subtropical surface waters from the north and colder, fresher subantarctic waters from the south, and have thus the potential to record past changes in the characteristics and confluence of these water masses. We first describe SST changes for the area west of New Zealand (core SO136-GC3), which demonstrate a very high sensitivity to glacial/interglacial changes. We then present data from southeast of Tasmania (core FR1/94-GC3), which exhibit contrasting trends, particularly in the expression of SST during glacial stages. Subsequently, we discuss both reconstructions in a more global context and offer some insight into the differences between the last and penultimate glacial stages.

\section{Sediment cores and modern oceanographic setting}

Core SO136-GC3 $\left(42^{\circ} 18^{\prime} \mathrm{S}, 169^{\circ} 53^{\prime} \mathrm{E}, 958 \mathrm{~m}\right.$ water depth, $7.7 \mathrm{~m}$ recovered) was retrieved in 1998 (TASQWA cruise of the $R V$ Sonne) from the gentlysloping flank of the southern Challenger Plateau west of South Island of New Zealand (Fig. 1). Parasound profiling shows a flat sea floor and parallel sub-bottom reflectors to at least $70 \mathrm{~m}$ below the sea bed (Thiede et al., 1999). Core FR1/94-GC3 (441ㄴ' S, 149 59' E, $2667 \mathrm{~m}$ water depth; $4.7 \mathrm{~m}$ long) was recovered in 1994 ( $R V$ Franklin) from the East Tasman Plateau (Fig. 1), and it has already been the focus of other palaeoceanographic studies (Hiramatsu and De Deckker, 1997; Nees, 1997; Calvo et al., 2004).
Both cores are located in the South Tasman Sea, an area of confluence between warm and saline subtropical waters from the north and cold subantarctic waters with lower salinity from the south. Both water masses are delimited by the Subtropical Front (STF), which today lies south of our core locations, centered around $45^{\circ}-$ $47^{\circ} \mathrm{S}$ (Fig. 1). The STF is a dynamic, broadly-branched structure of steep surface horizontal temperature and salinity gradients that closely follow the $15^{\circ} \mathrm{C}$ surface isotherm in February, the $10^{\circ} \mathrm{C}$ isotherm in August and the 34.7-34.8\%o isohaline (Garner (1959), see also Belkin and Gordon (1996) for additional criteria for the STF identification). North of the STF, waters are influenced by the southward branch of the East Australian Current (EAC) that forms after bifurcation of the South Equatorial Current (SEC) upon reaching the Queensland coast $\left(\sim 14^{\circ}-18^{\circ} \mathrm{S}\right.$; Fig. 1). About half of the transport from the EAC $(\sim 15 \mathrm{~Sv})$ detaches the coast south of $30^{\circ} \mathrm{S}$ as a response to surface wind field stress (Tilburg et al., 2001). Upon separation, a series of meanders develop, with the main component of the flow being located between $33^{\circ}$ and $35^{\circ} \mathrm{S}$, forming the Tasman Front (TF) (Ridgway and Dunn, 2003). This front, which marks the boundary between the warm water of the Coral Sea and the colder water of the Tasman Sea, develops in the form of complex meanders influenced by regional topography (Ridgway and Dunn, 2003; Tomczak and Godfrey, 2003) and its average location can be defined based on satellite imagery (Mulhearn, 1987)(Fig. 1). Associated with the EAC and the TF, warm and cold core eddies develop, and often remnants of them can be encountered in the region south of the TF (Fig. 1). Ultimately, part of the flow is deflected towards the south as currents approach New Zealand due, in part, to the existence of the Challenger Plateau. This current feeds directly into the Southland Current (Fig. 1), which flows around the southern tip of the New Zealand South Island (Stanton, 1976). Eventually, a residual extension of the EAC continues southward along the Australian coast, reaching the east coast of Tasmania (Ridgway and Dunn, 2003).

Palaeoceanographic studies have revealed slight excursions of both, the TF and the STF in the past (Martinez, 1994, 1997; Passlow et al., 1997; Barrows et al., 2000; Kawagata, 2001; Kawahata, 2002). During the Last Glacial Maximum (LGM), for instance, the TF might have migrated northward from $\sim 30^{\circ} \mathrm{S}$ to $\sim 26^{\circ}$ $\mathrm{S}$, as inferred from the planktonic foraminiferal abundances (e.g. Martinez, 1994; Barrows et al., 2000; Barrows and Juggins, 2005). In relation to the STF, northward excursions in the vicinity of the East Tasman Plateau also seemed to have occurred during the LGM 


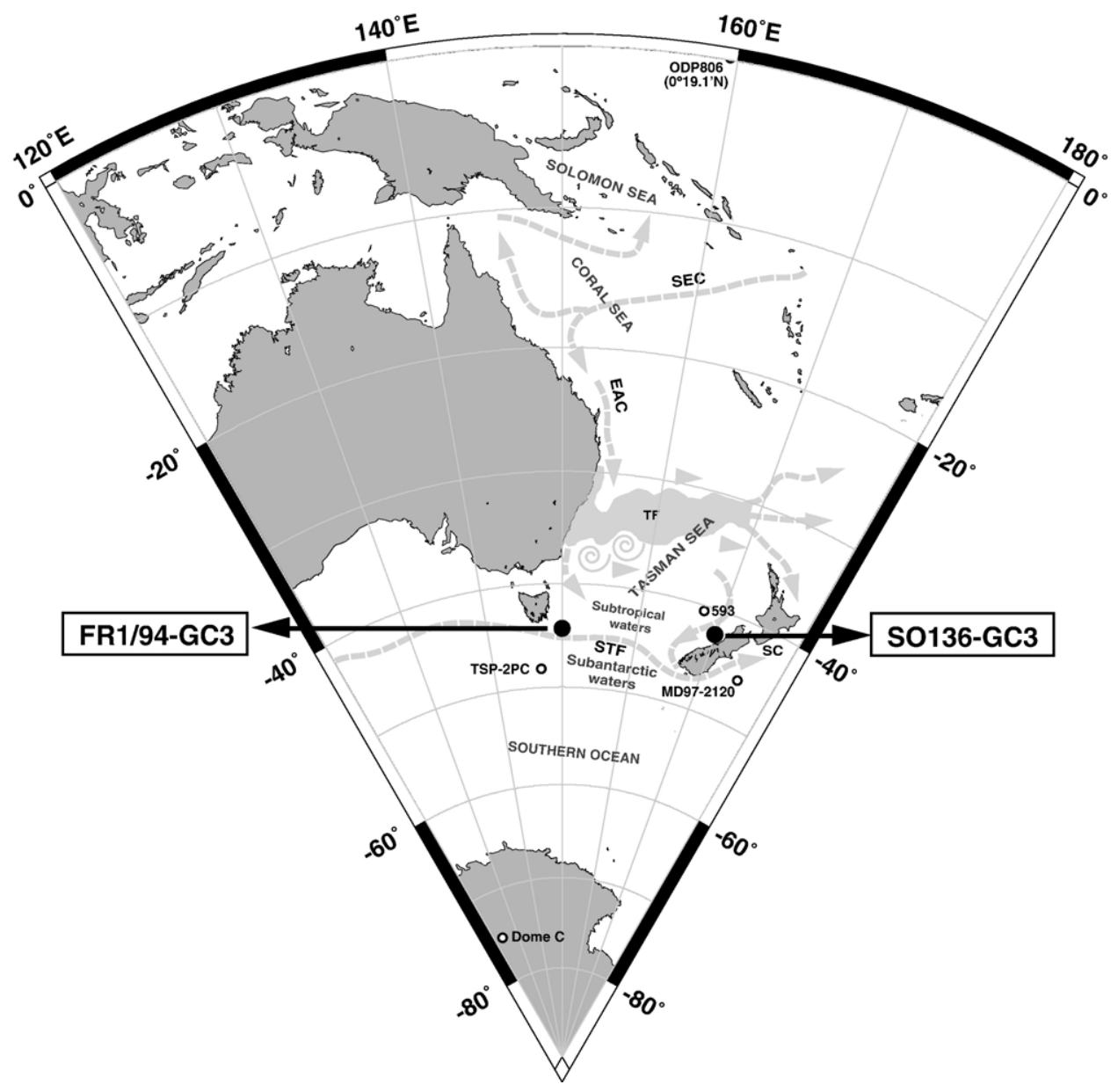

Fig. 1. Map showing locations of marine cores discussed in this study and approximate paths and distribution of relevant fronts and main currents according to Garner (1959), Mulhearn (1987), Ridgway and Dunn (2003), Stanton (1976), Tilburg et al. (2001) and Tomczak and Godfrey (2003) (please refer to these works for more detail on specific paths of oceanic currents and fronts. Note that the shaded area corresponding to the Tasman Front (TF) includes the Tasman Sea region where this oscillating front can be found with most probability). $U_{37}^{\mathrm{K}}$-SST data presented in this work corresponds to marine cores with filled black circles. Abbreviations are as follows: $\mathrm{SEC}=$ South Equatorial Current; EAC $=$ East Australian Current; $\mathrm{TF}=$ Tasman Front; STF=Subtropical Front; SC=Southland Current. Map built using the online map creation tool from GEOMAR (http://www. aquarius.geomar.de/omc/omc_intro.html) based on GMT software (Wessel and Smith, 1995). Spirals represent cold and warm core eddies, which usually develop in this area (Tomczak and Godfrey, 2003).

(e.g. Martinez, 1994; Nees, 1997; Passlow et al., 1997; Barrows et al., 2000).

\section{Methods}

\subsection{Alkenones and $U_{37}^{K^{\prime}}$}

$\mathrm{C}_{37}$ alkenone analyses for $U_{37}^{\mathrm{K}}$-SST estimations were performed at Geoscience Australia laboratories following a previous optimization of the pressurized liquid extraction technique (Calvo et al., 2003). Briefly, 3-4 g of freeze-dried sediment were loaded into $11 \mathrm{ml}$ stainless steel extraction cells of a Dionex ASE 200 pressurized liquid extraction system. After addition of an internal standard ( $n$-hexatriacontane) and subsequent extraction with dichloromethane, the extracts $(\sim 25 \mathrm{ml})$ were evaporated to dryness under a nitrogen stream. Following common methods (e.g. Villanueva et al., 1997), the evaporated extracts were hydrolysed overnight with $6 \%$ potassium hydroxide in methanol at room temperature, in order to eliminate hydrolysable material, especially wax esters, that may accumulate in the gas chromatography capillary columns. The neutral fraction was obtained after back extraction with $n$-hexane three times. Before evaporation, the $n$-hexane extracts were washed with $1 \mathrm{ml}$ of Milli-Q water to remove any $\mathrm{KOH}$ residue. The evaporated extracts were transferred to gas chromatography vials and derivatized with bis 
(trimethylsilyl) trifluoroacetamide. The derivatized extracts were then dissolved in toluene and injected in a Hewlett-Packard HP6890 Gas Chromatograph with a flame ionization detector (GC-FID), an on-column injector and equipped with a low bleed CP-Sil $5 \mathrm{CB}$ capillary column $(50 \mathrm{~m}, 0.32 \mathrm{~mm}$ I.D. and $0.12 \mu \mathrm{m}$ film thickness). Hydrogen was used as the carrier gas and the oven was programmed from $90{ }^{\circ} \mathrm{C}$ (holding time of $1 \mathrm{~min}$ ) to $160{ }^{\circ} \mathrm{C}$ at $15{ }^{\circ} \mathrm{C} / \mathrm{min}, 160{ }^{\circ} \mathrm{C}$ to $280{ }^{\circ} \mathrm{C}$ at $10{ }^{\circ} \mathrm{C} / \mathrm{min}$ with $30 \mathrm{~min}$ hold at $280^{\circ} \mathrm{C}$ and finally, from $280{ }^{\circ} \mathrm{C}$ to $310{ }^{\circ} \mathrm{C}$ at $6{ }^{\circ} \mathrm{C} / \mathrm{min}$ with a holding time of 6 min. Triplicate analyses of different aliquots of a sedimentary mixture with an alkenone content similar to the studied samples gave an analytical estimated uncertainty of $\pm 0.04{ }^{\circ} \mathrm{C}$ (see a comment on errors in SST estimations below). Selected samples were analyzed by GC-MS for confirmation of compound identification and to discard possible coelutions, using a Hewlett-Packard HP5973 MSD attached to an HP6890 GC and with the same low bleed CP-Sil 5 CB capillary column used in the GC-FID analysis. The mass spectrometer was operated at $70 \mathrm{eV}$ in full scan mode from 50 to $600 \mathrm{~m} / \mathrm{z}$.

$U_{37}^{\mathrm{K}}$ values were translated into SST using the relationship $U_{37}^{K^{\prime}}=0.033 \times \mathrm{SST}+0.044\left(r^{2}=0.958\right.$; Müller et al., 1998), which provides annually averaged SSTs, as suggested by the precise match between our estimated SST and World Ocean Atlas 1994 (Levitus, 1994) annual average temperatures at $0 \mathrm{~m}$ depth $(14.0$ versus $13.5^{\circ} \mathrm{C}$ for FR1/94-GC3 and 15.4 versus $15.3{ }^{\circ} \mathrm{C}$ for SO136-GC3, respectively). Regarding errors in SST estimations, the standard error using the global core-top calibration is $\pm 1.5{ }^{\circ} \mathrm{C}$ (Müller et al., 1998). However, this error should be taken as the largest possible uncertainty in the estimations since it contains measurements performed by a variety of laboratories and from oceanic regimes around the world. In our case, $U_{37}^{\mathrm{K}}$-SST for uppermost samples match within $0.5{ }^{\circ} \mathrm{C}$ with modern temperatures, a result that suggests uncertainties better than $\pm 1.5{ }^{\circ} \mathrm{C}$ in the location studied.

\subsection{Age models}

The age model for the uppermost part of core SO136GC3 was established using a basic spline fit with no smoothing through $14{ }^{14} \mathrm{C}$-Accelerator Mass Spectrometry (AMS) dates (Barrows et al., submitted for publication). For the older part of this core (beyond $38 \mathrm{kyr} \mathrm{BP}$ ), the model was constructed using planktonic foraminifera $\delta^{18} \mathrm{O}$ data (Fig. 3) correlated with the SPECMAP chronology of Martinson et al. (1987) (see also Pelejero et al., 2003). For FR1/94-GC3, no ${ }^{14} \mathrm{C}$ -
AMS dates were used, and Globigerina bulloides $\delta^{18} \mathrm{O}$ data was correlated with the SPECMAP chronology (see also Calvo et al., 2004). The age models provide sedimentation rates between 0.5 and $2.5 \mathrm{~cm}$ per kyr in core FR1/94-GC3, and between 1.5 and $6 \mathrm{~cm}$ per kyr in core SO136-GC3. Thus, the latter core allows a more detailed study on a higher time resolution, whereas core FR1/94-GC3 provides less detail but extends further back in time, to about $460 \mathrm{kyr} \mathrm{BP}$, prior to Marine Isotopic Stage (MIS) 12. In general, sedimentation rates are higher during deglaciations in both cores, and therefore these time horizons are represented in more detail. Terminations I and II in core SO136-GC3, for instance, for which a $2 \mathrm{~cm}$ sampling was performed, allow for a time resolution of about 300 to 600 years per sampled horizon.

\section{Results and discussion}

\subsection{SST during glacials and interglacials west of New Zealand}

\subsubsection{Interglacial stages 7, 5 and the Holocene}

The most prominent feature of the SST record from SO136-GC3 is found during the interglacials, which exhibit a consistent well-delimited interval of extreme warmth at the beginning of each period (Fig. 2). This structure is clear in MIS 7.5 and 5e, which evolved following almost identical histories, both in duration and in absolute SST values. Both stages reached extreme values of 19 to $19.5^{\circ} \mathrm{C}$, which were maintained for about $5 \mathrm{kyr}$, dropping abruptly afterwards to 14.5 and $15.4{ }^{\circ} \mathrm{C}$, respectively. The earliest part of the Holocene is also well represented by similar SST maxima, but over significantly lower temperatures, peaking only at $16.9^{\circ} \mathrm{C}$. In a recent study, Pelejero et al. (2003) discussed in detail the characteristics of MIS 5e in this core, and assessed possible scenarios during the extreme period of warmth. One highlighted idea, based on comparison of SSTs against an equatorial core (ODP806; Lea et al., 2000; Fig. 1), was that meridional SST gradients would have been significantly diminished during early MIS 5e. Taking into account the modern correlation between such meridional gradients and the El Niño Southern Oscillation (ENSO) phase, Pelejero et al. (2003) concluded that a prevalence of either persistent or more frequent La Niña-like conditions characterised early MIS 5e. Following the same rationale, and taking the same equatorial core as a reference, we suggest that analogous conditions would have developed during MIS 7.5. In fact, this situation would have probably been even more accentuated since 


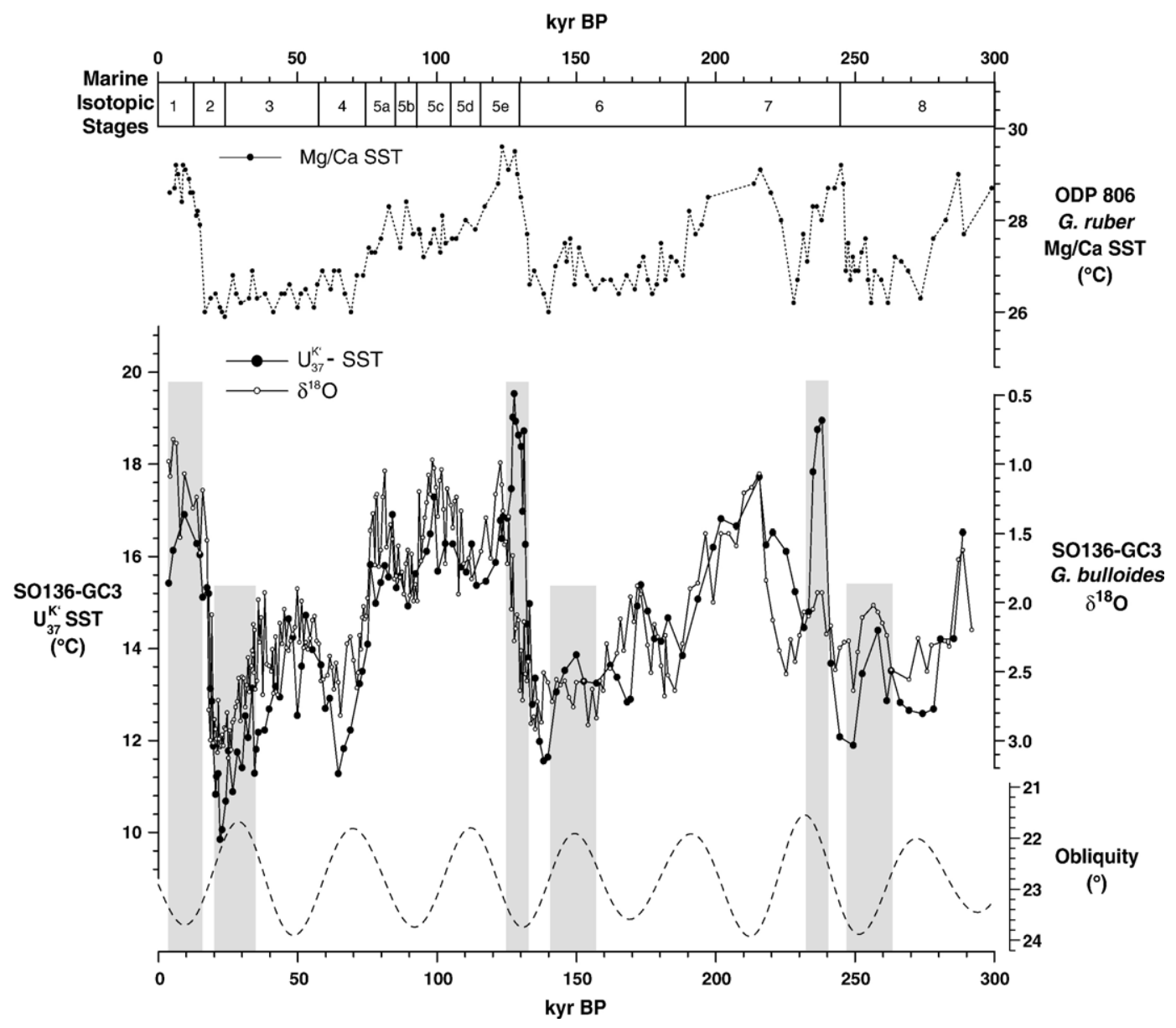

Fig. 2. Middle panel, G. bulloides $\delta^{18} \mathrm{O}$ and $U_{37}^{\mathrm{K}}$-SST for core SO136-GC3, west of New Zealand. Upper panel, G. ruber $\mathrm{Mg} / \mathrm{Ca}-\mathrm{SST}$ from equatorial Pacific core ODP 806 (Lea et al., 2000) for comparison and qualitative assessment of meridional gradients. In the lower panel we have depicted the oscillations of Earth obliquity (Laskar, 1990), note reversed axis. Short shaded areas highlight the conspicuous warm intervals prior to development of full glacial conditions before each deglaciation. Long shaded areas highlight conspicuous warm temperatures at the beginning of each interglacial stage.

equatorial temperatures during this period were not as warm as during MIS 5e (Fig. 2)(Lea et al., 2000). Concerning the early Holocene, temperatures off New Zealand did not reach the extreme warm conditions of MIS 7.5 and MIS 5e, so the meridional SST gradient to the equator did not diminish to such an extent. However, this gradient would have still been substantially lower than for the present day, with an estimated temperature difference between SO136-GC3 and ODP806 of about $12.3{ }^{\circ} \mathrm{C}$, compared to a modern gradient of more than $14{ }^{\circ} \mathrm{C}$ (Pelejero et al., 2003).

\subsubsection{Glacial stages}

Core SO136-GC3 includes the full glaciations MIS 8, 6, 4 and 2 (Fig. 2). Minimum temperature obtained for these periods show a decreasing trend from past to present, with values of $11.9,11.6,11.3$ and $9.8{ }^{\circ} \mathrm{C}$, respectively. As we discuss in the following sections, this trend is opposite to our SST reconstruction for FR1/ 94-GC3.

Before terminations, glacial stages recorded in SO136-GC3 contain a conspicuous period of warmth well before the timing of the coldest SST (Fig. 2). Analogous patterns of warmth predating maximum cooling have been reported elsewhere (e.g. North Atlantic Ocean (Calvo et al., 2001) and South Atlantic Ocean (Sachs et al., 2001)). In the latter study, where a very similar period of warmth, both in duration and temperature amplitude, was recognised, a close match to the orbital forcing component of obliquity was seen. It was then proposed, following the modelling rationale of Gallimore and Kutzbach (1995), that variations of obliquity might play an important role in modulating mid-latitude temperatures in the Southern Hemisphere. 
A decrease in Earth tilt, as occurred during the period of SST warmth would result in warming at low latitudes and cooling at high latitudes. In Fig. 2, where we have represented (inverted axis) the obliquity evolution together with SST reconstructions off New Zealand, there is agreement between low Earth tilt and the preglacial warming before Terminations I and II. Thus, an obliquity favoured warming of low latitudes might have been expressed further south, reaching our site west of New Zealand. There is no correlation with low obliquity, however, for the event predating Termination III, prior to $250 \mathrm{kyr} \mathrm{BP}$, which suggests that there might not be a causal effect between both parameters, or the mechanisms explaining the three warming events are not the same. Similar features of warmth predating glacial maxima and Terminations were also observed in reconstructed SSTs east of New Zealand, particularly before Terminations III and II, but were not so clear prior to Termination I (Pahnke et al., 2003).

\subsection{SST during glacials and interglacials southeast of Tasmania}

\subsubsection{Interglacial stage 11}

Amongst previous interglacial periods, Stage 11 stands out as the most similar to the Holocene for its comparable Earth's orbital parameters. For this reason, it has been often regarded as a good analogue to present times (Howard, 1997; Loutre and Berger, 2003). Several characteristics have been highlighted for this interglacial (see review by Droxler et al. (2003) and papers therein): maximum temperature seems to have lasted longer than usual $(\geq 20 \mathrm{kyr}$; Hodell et al., 2000), sea level was probably significantly higher than today, about $+20 \mathrm{~m}$ in some estimations (e.g. Hearty et al., 1999) and, regarding maximum temperature, it appears to have been warmer than today in certain areas (e.g. Western Europe (Rousseau et al., 1992), Equatorial Pacific (Lea et al., 2000) and California margin (Herbert et al., 2001)) but similar or colder in others (e.g. South Atlantic sector of the Southern Ocean (Hodell et al., 2000) and references therein).

Our estimates for MIS 11 indicate that SST southeast of Tasmania was comparable to today, averaging $13.7{ }^{\circ} \mathrm{C}$ (Fig. 3). This result is also coincident with SSTs east of New Zealand estimated from foraminiferal transfer functions (King and Howard, 2000) pointing towards a general feature in this region. Temperature similar to today for MIS 11 has also been reported in the Atlantic sector of the Southern Ocean (Hodell et al., 2000) and the North Atlantic (McManus et al., 1999).

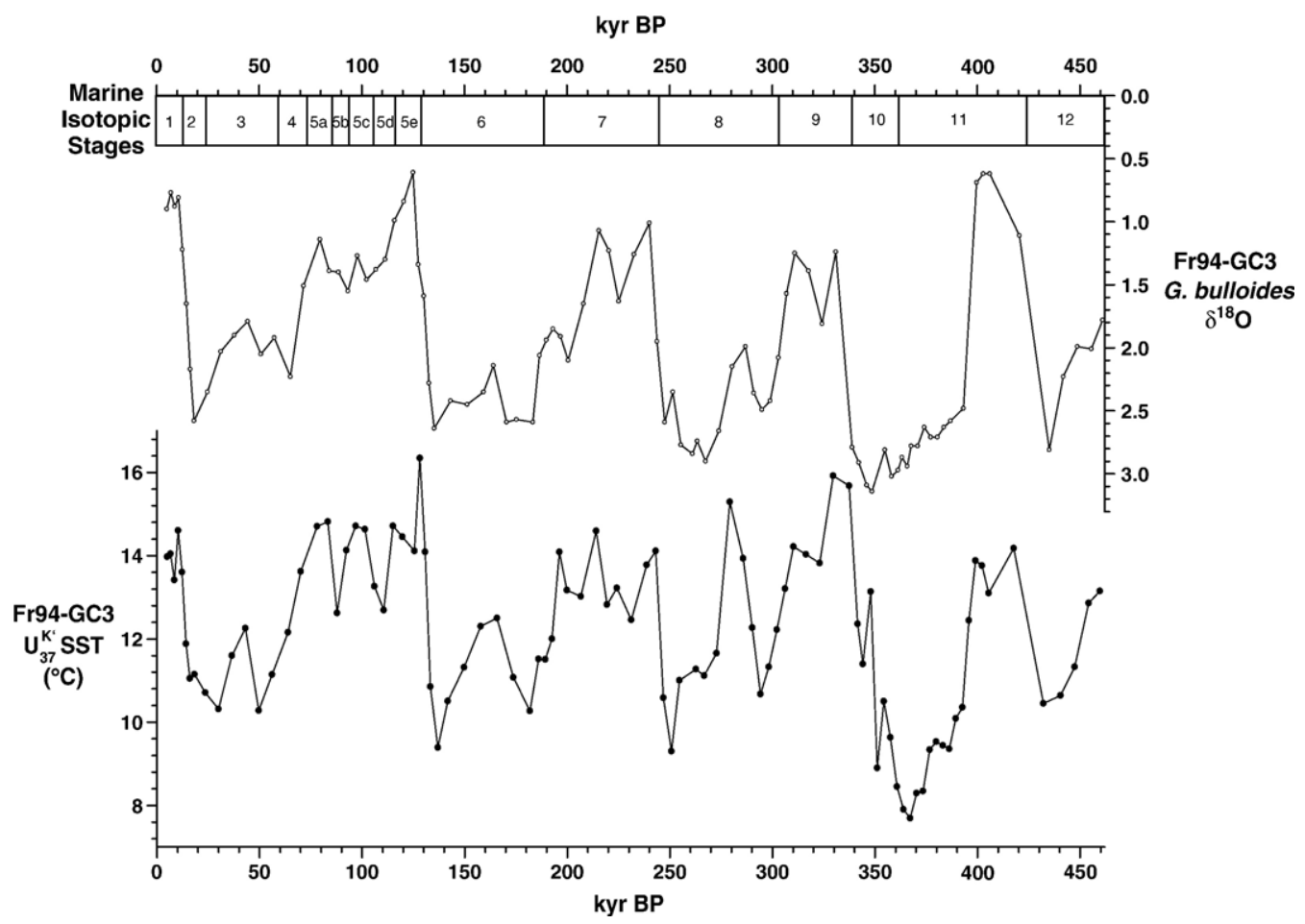

Fig. 3. G. bulloides $\delta^{18} \mathrm{O}$ and $U_{37}^{\mathrm{K}}$-SST for core FR1/94-GC3, southeast of Tasmania. 
On the other hand, the $\delta \mathrm{D}$ record of Vostok in Antarctica (Petit et al., 1999), recently replicated at Dome C (Augustin et al., 2004), also displays the same trend, with temperature during MIS 11 being similar to the Holocene and lower than during MIS 9c, 7e and 5e (Fig. 4). Thus, exceptional warming during MIS 11 might have characterised certain locations but was not global in nature.
In contrast to SST estimations, G. bulloides $\delta^{18} \mathrm{O}$ for core FR1/94-GC3 exhibit values lighter than modern times (Fig 3) and, when assessed in combination with SST data, might support the idea that sea level was significantly higher than today. In terms of duration, MIS 11 southeast of Tasmania seems to have been longer than the rest of interglacials, with maximum temperatures lasting for about $20 \mathrm{kyr}$. A possible

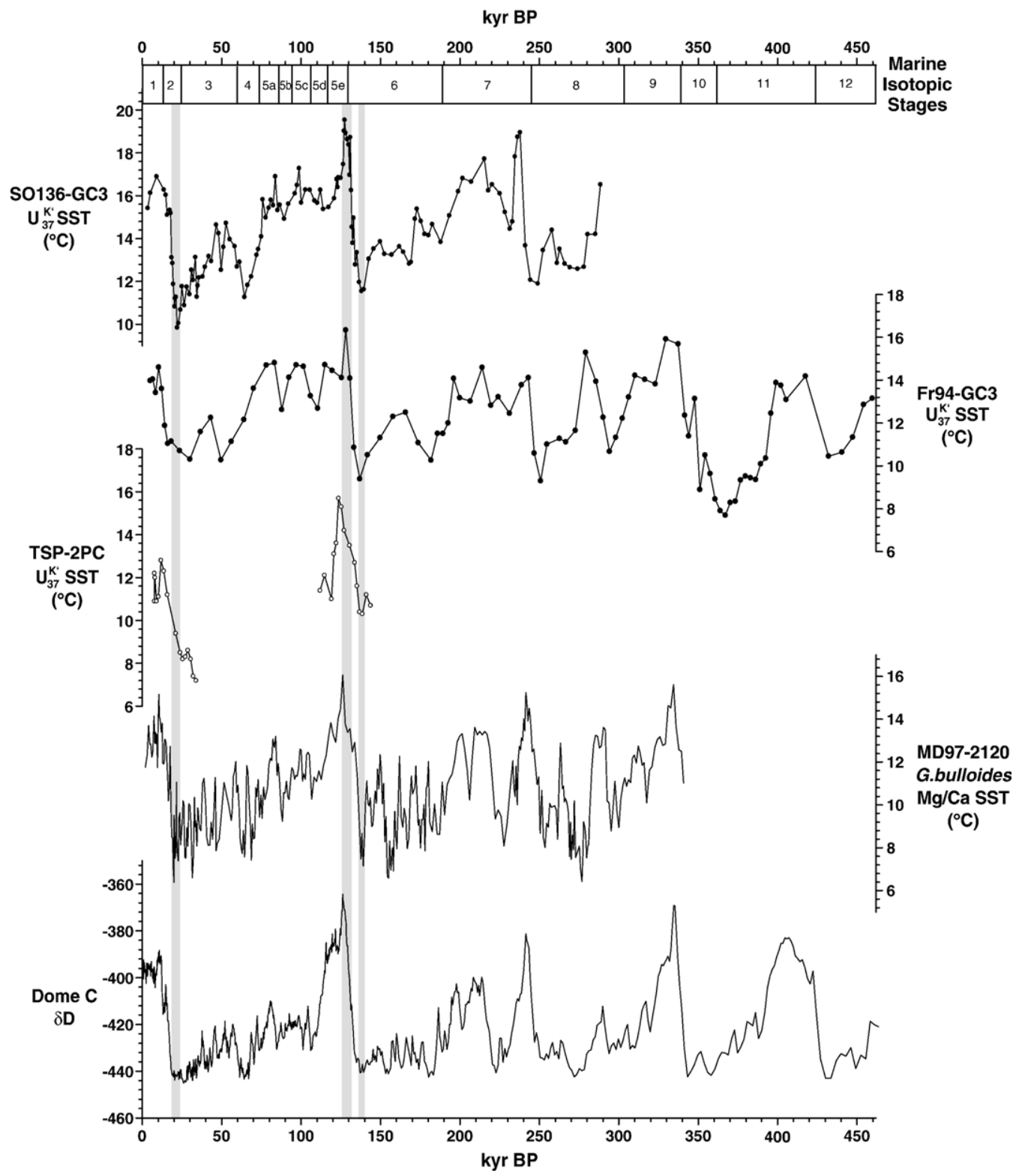

Fig. 4. From upper to lower panel, records of $U_{37}^{K^{\prime}}$-SST for core SO136-GC3, $U_{37}^{K^{\prime}}$-SST for core FR1/94-GC3, $U_{37}^{K^{\prime}}$-SST for core TSP-2PC (Ikehara et al., 1997), G. bulloides Mg/Ca-SST for core MD97-2120 (Pahnke et al., 2003) and $\delta \mathrm{D}$ from Dome C, a proxy for air temperature in Antarctica (Augustin et al., 2004). Gray bars correspond to selected time horizons used to construct maps as presented in Fig. 5. Note that all SST increments have been plotted over the same scales to better assess changes in SST amplitude between different locations. 
explanation for this longer duration takes into account the low eccentricity that characterises this period, with the consequent dampening of the precession amplitude (Hodell et al., 2000). This situation prevents the development of strong cold substages and thus promotes the continuation of stable and warm interglacial conditions. A very similar pattern of MIS 11 alkenone temperatures in terms of duration was found in the northern limb of the California Current (Herbert et al., 2001).

\subsubsection{Interglacial stages 9, 7, 5 and the Holocene}

SST during MIS 9 reached a maximum of $15.9^{\circ} \mathrm{C}$, making it the warmest interglacial other than MIS 5e, which still experienced temperatures slightly warmer than present $\left(16.3{ }^{\circ} \mathrm{C}\right.$; Fig. 3). It is interesting to remark that such warm temperatures during MIS 9 developed after the coldest glacial stage in our record, resulting in the largest glacial to interglacial SST shift (MIS 10 to MIS 9) of more than $8{ }^{\circ} \mathrm{C}$ of SST increase (from 7.7 to $15.9{ }^{\circ} \mathrm{C}$, Table 1). Following MIS 9, and after reaching mild glacial conditions during MIS 8.6 $\left(10.7^{\circ} \mathrm{C}\right)$, SSTs peaked again to levels very close to those registered during MIS $9\left(15.3^{\circ} \mathrm{C}\right)$, a warm event ascribed to MIS 8.5. MIS 7 is well represented by the three classical, distinct warm substages, reaching nearly the same SSTs during each of them (14.1, 14.6 and $14.1{ }^{\circ} \mathrm{C}$ for MIS 7.5, 7.3 and 7.1, respectively; Fig. 3). This scenario resembles the $\mathrm{Mg} / \mathrm{Ca}$ SST record from southeast of New Zealand (Pahnke et al., 2003).

From MIS 5e to the present, the SST record from FR1/94-GC3 has very similar features to SO136GC3. MIS 5e, although recorded at a much lower resolution than in SO136-GC3, is also represented as a brief and extremely warm period, exhibiting the highest temperatures in the whole record $\left(16.3{ }^{\circ} \mathrm{C}\right)$. Subsequently, warm substages $5 \mathrm{c}$ and $5 \mathrm{a}$ reached approximately the same SST $\left(\sim 14.7{ }^{\circ} \mathrm{C}\right)$, being preceded by cold substages $5 \mathrm{~d}$ and $5 \mathrm{~b}$ of very similar temperature $\left(\sim 12.6{ }^{\circ} \mathrm{C}\right)$. The warmest temperature recorded during the early Holocene is $14.6^{\circ} \mathrm{C}$, being very similar to MIS $5 \mathrm{c}$ and $5 \mathrm{a}$. This is followed by a moderate cooling of about $0.5{ }^{\circ} \mathrm{C}$, a trend consistent with the reconstruction off New Zealand. There is thus an apparent consistency pointing towards a warmer early Holocene similar to the history of MIS 5e. This Holocene trend matches SST records observed with alkenones east of New Zealand (Sikes et al., 2002) and in other areas like the North Atlantic Ocean and the Mediterranean Sea (see review by Marchal et al., 2002).

\subsubsection{Glacial stages}

Core FR1/94-GC3 extends over glacial Stages 12 to 2 (Fig. 3). Contrary to our SST reconstruction for SO136-GC3, and with the exception of MIS 12, there is a clear decreasing tendency of maximum cooling from past to present, with values of 7.7, 9.3, 9.4 and $10.3{ }^{\circ} \mathrm{C}$ for MIS $10,8,6$ and 4 to 2, respectively. This result adds to previous observations of a similar trend in the southern Indian Ocean (southwest Australia) at equivalent latitudes (Howard and Prell, 1992). As we discuss below, the different patterns between SO136GC3 and FR1/94-GC3 might be indicative of significant changes in the oceanographic setting of the southern part of the Tasman Sea during these cold stages.

MIS 12 as represented in FR1/94-GC3 is exceptional, with very mild temperatures $\left(10.5{ }^{\circ} \mathrm{C}\right)$ for a period that has often been characterised as one of the coldest glacial stages of the last $500 \mathrm{kyr}$ (Howard and Prell, 1992; Howard, 1997). A relatively mild MIS 12 has also been reported on several occasions, including the Devils Hole palaeotemperature record (Winograd et al., 1997) and a $\mathrm{Mg} / \mathrm{Ca} \mathrm{SST}$ record from the western equatorial Pacific (Lea et al., 2000), evidencing spatial heterogeneity in its climatic expression. In our reconstruction, it was indeed MIS 10 and not MIS 12, by far the coldest glacial period, reaching SSTs almost $3{ }^{\circ} \mathrm{C}$ colder than MIS 12 (Fig. 3). This result contrasts with recent records from other southern high latitude realms, including the South Atlantic Subtropical Front, which experienced anomalously warm temperatures during MIS 10 (Cortese et al., 2004).

\subsection{Comparative picture and some insights for selected time slices}

\subsubsection{SST change during glacial interglacial transitions}

In Table 1, we have calculated the amplitude of $U_{37^{-}}^{\mathrm{K}^{\prime}}$ SST change for the last four glacial/interglacial transitions. As mentioned above, the largest SST change corresponds to Termination IV south of Tasmania, with an increase of more than $8{ }^{\circ} \mathrm{C}$. The next most important SST change occurred west of New Zealand during Termination II, with a rise of nearly $8^{\circ} \mathrm{C}$ in SST. Indeed, this termination was fairly large in amplitude south of Tasmania as well, with $6.9{ }^{\circ} \mathrm{C}$. For the last three Terminations, which are covered by both cores, SST changes west of New Zealand have always been of larger amplitude than south of Tasmania. Thus, New Zealand seems to have been more sensitive to orbital 
Table 1

Amplitude of $U_{37^{-}}^{\mathrm{K}}$-SST change $\left({ }^{\circ} \mathrm{C}\right)$ for the last four Terminations*

\begin{tabular}{llll}
\hline Core & From & To & Total difference \\
\hline Termination I & & & \\
FR1/94-GC3 & 10.3 & 14.6 & 4.3 \\
SO136-GC3 & 9.8 & 16.9 & 7.1 \\
Termination II & & & \\
FR1/94-GC3 & 9.4 & 16.3 & 6.9 \\
SO136-GC3 & 11.6 & 19.5 & 7.9 \\
Termination III & & & \\
FR1/94-GC3 & 9.3 & 14.1 & 4.8 \\
SO136-GC3 & 11.9 & 19 & 7.1 \\
& & & \\
Termination IV & & 15.9 & 8.2 \\
FR1/94-GC3 & 7.7 & & \\
\hline
\end{tabular}

*SST values taken are coldest and warmest prior and subsequent to each glacial/interglacial change.

glacial/interglacial changes than the area south of Tasmania. A similar result was found in SST reconstructions based on foraminiferal assemblages, where higher amplitude cooling during the LGM $\left(6^{\circ}\right.$ to $\left.10^{\circ} \mathrm{C}\right)$ was found over the Campbell Plateau, southeast of New Zealand, as compared to west of Tasmania $\left(2^{\circ}\right.$ to $5{ }^{\circ} \mathrm{C}$; Barrows et al. (2000) which includes data from FR1/94GC3). Another example of high climatic sensitivity west of New Zealand is the expression of MIS 5e discussed above, a period of extreme warmth that explains the large SST change associated with Termination II. Perhaps this particular sensitivity results from a strong influence of changes in the configuration and strength of the EAC, probably linked to the expansion and contraction of the Western Pacific Warm Pool (WPWP).

\subsubsection{Trends in coldest glacial SSTs and MIS 6 versus MIS 2 temperatures}

As mentioned above, one of the most remarkable differences between both records is the general trend of maximum cooling from past to present. In SO136-GC3, coldest glacial SST display a decreasing trend, while in FR1/94-GC3 SST increase progressively, with warmest values documented for the LGM (Fig. 4). Consequently, this different evolution results in a convergence of absolute SSTs between both cores, which effectively culminates in approximately the same values during the LGM.

The existence of these contrasting trends results in important differences in the expression of the SST difference between glacial MIS 6 and 2, an issue that has raised considerable debate amongst palaeoceanographers when reconstructing SST (Schneider et al., 1999; Herbert, 2004). Part of the conundrum arises from the general view that alkenone palaeothermometry usually represents a MIS 6 warmer than MIS 2, a feature often not expressed in foraminifera $\delta^{18} \mathrm{O}$ data and foraminiferal assemblages for the same cores. Examples of this result can be found in reconstructions from the North Atlantic (Eglinton et al., 1992; Madureira et al., 1997; Villanueva et al., 1998), Equatorial Atlantic (Wolff et al., 1999), South Atlantic (Schneider et al., 1995; Kirst et al., 1999), Indian (Rostek et al., 1993, 1997; Emeis et al., 1995), east-equatorial and north Pacific Oceans (Lyle et al., 1992; Herbert et al., 2001) and the South China Sea (Pelejero et al., 1999a,b; Wang et al., 1999). It is important to note, however, that for certain areas, similar SST values for MIS 6 and MIS 2 have also been obtained with the alkenone method. Examples of this are several records under the influence of the Benguela Coastal Current (Kirst et al., 1999; Schneider et al., 1999) and cores from the North Atlantic (Calvo et al., 2001; Sicre et al., 2000).

Another palaeothermometer that has gained broad acceptance amongst palaeoceanographers is based on the $\mathrm{Mg} / \mathrm{Ca}$ ratio of foraminifera. Unfortunately, parallel measurements of $U_{37}^{\mathrm{K}}$ and $\mathrm{Mg} / \mathrm{Ca}$ in the same sediment sections are still scarce, with only one publication to date covering MIS 6 and MIS 2 (Nürnberg et al., 2000). Interestingly, this study presents similar $\mathrm{Mg} / \mathrm{Ca}$ and $U_{37}^{\mathrm{K}}$-SST histories, clearly expressing a MIS 6 warmer than MIS 2 with both methods for two cores from the tropical Atlantic. Similarly, foraminifera $\mathrm{Mg} / \mathrm{Ca}$ from the equatorial Atlantic and Caribbean Sea also showed a MIS 6 warmer than MIS 2 (Hastings et al., 1998). Other areas studied by means of foraminifera $\mathrm{Mg} / \mathrm{Ca}$ have provided, however, comparable MIS 6 and MIS 2 SST (e.g. Lea et al. (2000); Visser et al. (2003), both studies from equatorial areas).

In the case of the South Tasman Sea, our studied cores express SSTs from $U_{37}^{\mathrm{K}}$ for MIS 6 and MIS 2 in opposite ways. MIS 6 was warmer than MIS 2 in SO136-GC3 but slightly colder than MIS 2 in FR1/94GC3 (Fig. 4). It is important to note that, in both cases, $U_{37}^{K}$-SST differences between these stages are accompanied by similar trends in enrichment or depletion of planktonic foraminifera $\delta^{18} \mathrm{O}$ (Figs. 2 and 3; although the latter measurement includes salinity and ice volume changes in addition to SST). Concerning the comparison between MIS 6 and MIS 2, a result similar to our reconstruction for FR1/94-GC3 was found east of New Zealand using foraminifera $\mathrm{Mg} / \mathrm{Ca}$ (Fig. 4; Pahnke et al., 2003). In addition, data on planktonic foraminifera faunas from two cores south of Tasmania also indicated a particularly cold MIS 6 (as compared to MIS 2) that involved the maximum northward displacement of the 
STF over the last 150 kyrs (Martinez, 1994; Passlow et al., 1997).

In summary, although MIS 6 has often been found warmer than MIS 2, this is not the general rule worldwide, and different oceanic basins responded in different ways during these two glacial periods. To some extent, temperature differences between MIS 6 and MIS 2 might have a latitudinal dependence. It is at the lower latitudes where a larger number of SST reconstructions indicate generally warmer SSTs for MIS 6 compared to MIS 2. More additional data on palaeotemperatures using different methods are needed to better understand the spatial oceanographic expression of the last and penultimate glacial stages. In particular, an exhaustive comparison of alkenone and foraminifera $\mathrm{Mg} / \mathrm{Ca}$ SSTs would help clarify whether differences exist depending on the method used in these particular glacial time slices.

\subsubsection{SST maps for selected periods}

In Fig. 5, we summarize the reconstructed SSTs for our two cores averaged over selected periods in order to illustrate, in a qualitative way, oceanographic differences between MIS 5e and modern times, and between MIS 6 and MIS 2, some periods that, a priori, one might consider rather analogous. In addition, we include SST data from cores TSP-2PC (Ikehara et al., 1997) and MD97-2120 (Pahnke et al., 2003). In the latter case, SSTs were derived from $G$. bulloides $\mathrm{Mg} / \mathrm{Ca}$ ratios, a species that calcifies mostly during austral spring (King and Howard, 2001), and thus records a temperature rather similar to the annual mean, which is the temperature represented by our method. In fact, the uppermost section of MD97-2120 provides a SST of $11.8^{\circ} \mathrm{C}$ (Pahnke et al., 2003), which is very close to the World Ocean Atlas 1994 annual mean of $12.2{ }^{\circ} \mathrm{C}$ (Levitus, 1994).
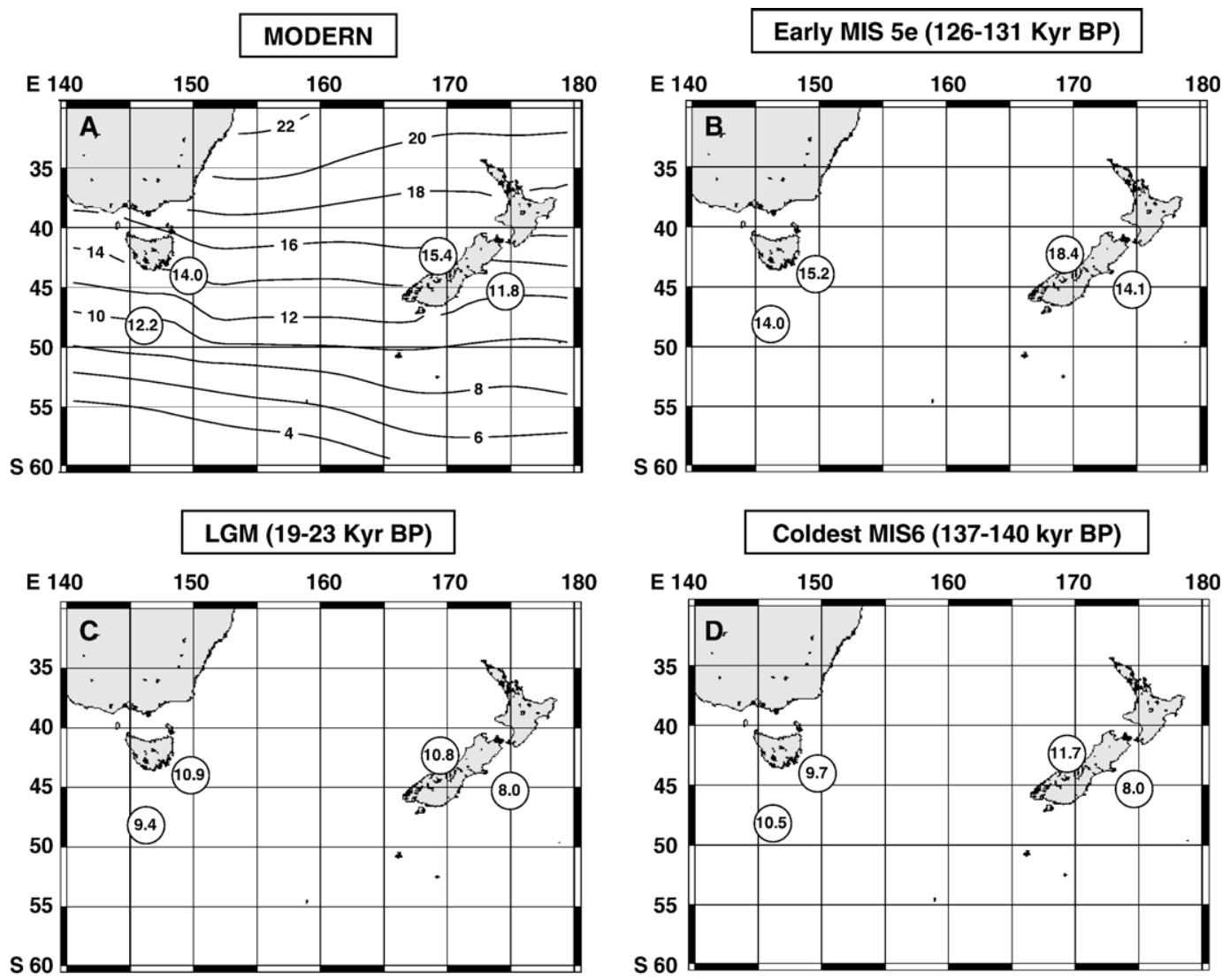

Fig. 5. SST maps for the three selected time horizons highlighted in Fig. 4, compared to modern conditions (data from World Ocean Atlas 1994, annual average at $0 \mathrm{~m}$ depth (Levitus, 1994)). Represented in circles are reconstructed SSTs for our two studied cores, TSP-2PC (Ikehara et al., 1997) and MD97-2120 (Pahnke et al., 2003) averaged over the specific age intervals. For modern times, we have represented only the sedimentary uppermost reconstructed SST value, which in the case of TSP-2PC corresponds to the uppermost sample from multiple core TSP-2MC taken nearby (Ikehara et al., 2000). 
Modern mean annual isotherms on the map (Fig. 5A) have been constructed based on annual average data at $0 \mathrm{~m}$ depth from World Ocean Atlas 1994 (Levitus, 1994). Our reconstructed SST values for the uppermost sediment sections compare reasonably well with modern SST, the only exception being core TSP-2MC (a multiple core taken adjacent to piston core TSP-2PC (Ikehara et al., 2000)), that displays SSTs slightly warmer than modern. Since the ${ }^{14} \mathrm{C}$ age of this particular core-top is $7190 \mathrm{yr}$ BP (Ikehara et al., 2000) it probably represents warmer temperatures ascribed to the early Holocene.

The SST distribution was different during early MIS 5e (131-126 kyr BP; Fig. 5B), which was significantly warmer than modern times in all reconstructions. Amongst them, the area west of New Zealand experienced by far the largest SST increase in relation to modern times, with temperatures $3{ }^{\circ} \mathrm{C}$ warmer than the Holocene on average. Similar results were found for core DSDP 593, located further north, ((Nelson et al., 1994); Fig. 1; although based on planktonic foraminifera $\delta{ }^{18} \mathrm{O}$, a proxy subject to changes in salinity and ice volume in addition to SST). This configuration could be ascribed to a southern expansion of the WPWP and/or a southward migration of the TF and/or an intensification of the TF and major influence and supply of subtropical warm waters to the west coast of New Zealand.

Regarding the last and penultimate glacial reconstructions, we have averaged all reconstructed temperatures from 23 to $19 \mathrm{kyr}$ BP (following recommendations by Mix et al., 2001) and from 140 to $137 \mathrm{kyr}$ BP, respectively (Fig. 5C,D). The existence of similar SSTs between SO136-GC3 and FR1/94-GC3 during the LGM suggests that isotherms might have been bowed towards the north in the area west of New Zealand. A similar bowing of isotherms was found previously in SST reconstructions for the LGM based on foraminiferal assemblages (Barrows et al., 2000; Barrows and Juggins, 2005). As suggested by Barrows et al. (2000), a possible scenario could be a partial entrance of subantarctic waters associated to a northward shift of the STF in the Tasman Sea having a stronger impact along the west coast of New Zealand together with a still significant transport of warm subtropical water towards Tasmania associated to the East Australian Current. This situation contrasts with the SST estimate from SO136GC3 for MIS 6, which is warmer than MIS 2. In this case, the average configuration of isotherms might have been more compressed and/or changed in direction, with warmer temperatures in the east South Tasman Sea and colder temperatures towards Tasmania. $U_{37^{K}}^{K}$ SST data for TSP-2PC SST, however, do not fit adequately into this pattern, with values that appear slightly warmer than normal. Unfortunately, MIS 6 is not well covered by these $U_{37}^{K^{\prime}}$-SST data (Fig. 4; Ikehara et al., 1997) and it is difficult to confirm whether these SSTs truly represent MIS 6, or correspond to warmer deglacial values.

Overall, these summarized data illustrate the different latitudinal and regional expression of SSTs during MIS 6 as compared to MIS 2, and give support to previous results based on planktonic foraminifera faunal studies (Martinez, 1994, 1997; Passlow et al., 1997). In these studies, the area south of Tasmania was regarded as particularly cold during MIS 6 (as compared to MIS 2), being affected by a northward displacement of the STF. Conversely, Martinez (1994, 1997) suggested that the TF might have migrated northwards during the LGM but not during MIS 6, an oceanographic configuration that matches with our data on warmer SSTs during MIS 6 offshore New Zealand in comparison to southeast of Tasmania.

\section{Conclusions}

$U_{37}^{\mathrm{K}}$-SSTs are presented for two cores from the South Tasman Sea, one offshore west of New Zealand and the other southeast of Tasmania. The evolution and magnitude of change of SST in both records demonstrates a high degree of climate sensitivity, which is particularly enhanced offshore New Zealand. In this area, SST was significantly warmer than present during the start of all interglacial periods. During MIS 7.5 and early MIS 5e, SSTs reached values over $19{ }^{\circ} \mathrm{C}$, compared to modern temperatures of $\sim 15.4{ }^{\circ} \mathrm{C}$. This situation suggests significantly-altered meridional gradients of SST versus the equator during these periods, towards a configuration rather typical of a permanent or frequent La Niña phase. A conspicuous period of relative warmth occurred fairly systematically prior to development of full glacial conditions, before each deglaciation. Comparison between these intervals with periods of low obliquity suggests a possible link to a differentiated low to high latitude warming due to changes in this orbital parameter. However, no correlation exists prior to $250 \mathrm{kyr} \mathrm{BP}$, suggesting that there might not be a casual effect between both parameters, or the mechanisms explaining all warming events are not the same.

Core FR1/94-GC3 is the only one recording MIS 11, a period with SSTs similar to today, averaging $\sim 13.7{ }^{\circ} \mathrm{C}$. This result adds to additional evidence pointing towards global heterogeneity in the thermal characteristics of this interglacial, being warmer than today in some areas, but similar to modern times in other 
areas. Our data suggest, however, that its duration was probably longer than usual, a feature that seems global in nature. Amongst glacial stages, MIS 10 was by far the coldest, reaching SSTs almost $3{ }^{\circ} \mathrm{C}$ colder than MIS 12 .

The amplitude of SST change in both records is significant, with variations offshore New Zealand being consistently more important, reaching nearly $8{ }^{\circ} \mathrm{C}$ during Termination II. The area west of New Zealand thus shows an apparent higher sensitivity to climatic change on orbital time scales, and probably responds to expansions and contractions of the WPWP and/or the meridional migration and changes in intensity of currents associated with the TF. Concerning glacial stages in both cores, there is a contrasting trend of coldest glacial SSTs from past to present. In SO136GC3, coldest glacial temperatures generally decrease with time, while in FR1/94-GC3 glacial stages become warmer through time. This results in different oceanographic configurations of glacial stages through time. More specifically, MIS 6 and MIS 2 are recorded differently in both areas, with MIS 6 being warmer than MIS 2 west of New Zealand, but slightly colder southeast of Tasmania. In particular, the area west of New Zealand is probably more susceptible to lower latitude SST changes linked to specific configurations of the WPWP and the TF, while the area south of Tasmania is more indicative of thermal changes at high southern latitudes.

\section{Acknowledgements}

A. Sturm is acknowledged for the assistance with oxygen isotope analyses and J. Thiede and S. Nees for making available Sonne 136 cores and allowing us to study core SO136-GC3. We are also grateful to the Australian National Facility for use of the RV Franklin to obtain core FR1/94GC3. EC and CP acknowledge postdoctoral fellowships and funding from Australian Research Council (ARC) and Ramón y Cajal contracts from the Spanish Ministry of Education and Science. Funding for PDD and TTB to work on both FR1/94GC3 and SO136-GC3 was provided by the ARC. GAL publishes with permission of the CEO of Geoscience Australia.

\section{References}

Augustin, L., et al., 2004. Eight glacial cycles from an Antarctic ice core. Nature 429, 623-628.

Barrows, T.T., Juggins, S., 2005. Sea-surface temperatures around the Australian margin and Indian Ocean during the last glacial maximum. Quat. Sci. Rev. 24, 1017-1047.
Barrows, T.T., Juggins, S., De Deckker, P., Thiede, J., Martinez, J.I., 2000. Sea-surface temperatures of the southwest Pacific Ocean during the last glacial maximum. Paleoceanography 15, 95-109.

Barrows, T.T., Juggins, S., De Deckker, P., Calvo, E., Pelejero, C., submitted for publication. Long-term climate change in the Australian-New Zealand region. Paleoceanography.

Belkin, I.M., Gordon, A.L., 1996. Southern Ocean fronts from the Greenwich meridian to Tasmania. J. Geophys. Res. 101, 3675-3696.

Brassell, S.C., Eglinton, G., Marlowe, I.T., Pflaumann, U., Sarnthein, M., 1986. Molecular stratigraphy: a new tool for climatic assessment. Nature 320, 129-133.

Calvo, E., Villanueva, J., Grimalt, J.O., Boelaert, A., Labeyrie, L., 2001. New insights into the glacial latitudinal temperature gradients in the North Atlantic. Results from $U_{37^{\prime}}^{K}$-sea surface temperatures and terrigenous inputs. Earth Planet. Sci. Lett. 188, 509-519.

Calvo, E., Pelejero, C., Logan, G.A., 2003. Pressurized liquid extraction of selected molecular biomarkers in deep sea sediments used as proxies in paleoceanography. J. Chromatogr. A 989, 197-205.

Calvo, E., Pelejero, C., Logan, G.A., De Deckker, P., 2004. Dustinduced changes in phytoplankton composition in the Tasman Sea during the last four glacial cycles. Paleoceanography 19, doi:10.1029/2003PA000992.

Cortese, G., Abelmann, A., Gersonde, R., 2004. A glacial warm water anomaly in the subantarctic Atlantic Ocean, near the Agulhas Retroflection. Earth Planet. Sci. Lett. 222, 767-778.

Droxler, A.W., Poore, R.Z., Burckle, L.H., 2003. Earth's climate and orbital eccentricity: the marine isotope stage 11 question. American Geophysical Union, Washington, DC. 240 pp.

Eglinton, G., Bradshaw, S.A., Rosell, A., Sarnthein, M., Pflaumann, U., Tiedeman, R., 1992. Molecular record of secular temperature changes on 100-year timescales for glacial Terminations I, II and IV. Nature 356, 423-426.

Emeis, K.-C., Anderson, D.M., Doose, H., Kroon, D., Schulz-Bull, D., 1995. Sea-surface temperatures and the history of monsoon upwelling in the Northwest Arabian Sea during the last 500,000 years. Quat. Res. 43, 355-361.

Gallimore, R.G., Kutzbach, J.E., 1995. Snow cover and sea ice sensitivity to generic changes in earth orbital parameters. J. Geophys. Res. -Atmos. 100, 1103-1120.

Garner, D.M., 1959. The subtropical convergence in New Zealand waters. N. Z. J. Geol. Geophys. 2, 315-337.

Hastings, D.W., Russell, A.D., Emerson, S.R., 1998. Foraminiferal magnesium in globeriginoides sacculifer as a paleotemperature proxy. Paleoceanography 13, 161-169.

Hearty, P.J., Kindler, P., Cheng, H., Edwards, R.L., 1999. A +20 m middle Pleistocene sea-level highstand (Bermuda and the Bahamas) due to partial collapse of Antarctic ice. Geology 27, 375-378.

Herbert, T.D., 2004. Alkenone paleotemperature determinations. In: Holland, H.D., Turekian, K.K. (Eds.), Treatise on Geochemistry. Elsevier Pergamon, Oxford, UK, pp. 391-432.

Herbert, T.D., Schuffert, J.D., Andreasen, D., Heusser, L., Lyle, M., Mix, A., Ravelo, A.C., Stott, L.D., Herguera, J.-C., 2001. Collapse of the California Current during glacial maxima linked to climate change on land. Science 293, 71-76.

Hiramatsu, C., De Deckker, P., 1997. The late Quaternary calcareous nannoplankton assemblages from three cores from the Tasman Sea. Palaeogeogr. Palaeoclimatol. Palaeoecol. 131, 391-412. 
Hodell, D.A., Charles, C.D., Ninnemann, U.S., 2000. Comparison of interglacial stages in the South Atlantic sector of the southern ocean for the past $450 \mathrm{kyr}$ : implifications for Marine Isotope Stage (MIS) 11. Glob. Planet. Change 24, 7-26.

Howard, W.R., 1997. A warm future in the past. Nature 388, $418-419$.

Howard, W.R., Prell, W.L., 1992. Late Quaternary surface circulation of the Southern Indian Ocean and its relationship to orbital variations. Paleoceanography 7, 79-117.

Ikehara, M., Kawamura, K., Ohkouchi, N., Kimoto, K., Murayama, M., Nakamura, T., Oba, T., Taira, A., 1997. Alkenone sea surface temperature in the Southern Ocean for the last two deglaciations. Geophys. Res. Lett. 24, 679-682.

Ikehara, M., Kawamura, K., Ohkouchi, N., Murayama, M., Nakamura, T., Taira, A., 2000. Variations of terrestrial input and marine productivity in the Southern Ocean $\left(48^{\circ} \mathrm{S}\right)$ during the last two deglaciations. Paleoceanography $15,170-180$.

Kawagata, S., 2001. Tasman front shifts and associated paleoceanographic changes during the last 250,000 years; foraminiferal evidence from the Lord Howe Rise. Mar. Micropal. 41, 167-191.

Kawahata, H., 2002. Shifts in oceanic and atmospheric boundaries in the Tasman Sea (Southwest Pacific) during the Late Pleistocene: evidence from organic carbon and lithogenic fluxes. Palaeogeogr. Palaeoclimatol. Palaeoecol. 184, 225-249.

King, A.L., Howard, W.R., 2000. Middle Pleistocene sea-surface temperature change in the Southwest Pacific Ocean on orbital and suborbital time scales. Geology 28, 659-662.

King, A.L., Howard, W.R., 2001. Seasonality of foraminiferal flux in sediment traps at Chatham Rise, SW Pacific: implications for paleotemperature estimates. Deep-Sea Res., Part I, Oceanogr. Res. Pap. 48, 1687-1708.

Kirst, G.J., Schneider, R.R., Müller, P.J., von Storch, I., Wefer, G., 1999. Late Quaternary temperature variability in the Bengela Current system derived from alkenones. Quat. Res. 52, 92-103.

Laskar, J., 1990. The chaotic motion of the solar system: a numerical estimate of the chaotic zones. Icarus 88, 266-291.

Lea, D.W., Pak, D.K., Spero, H.J., 2000. Climate impact of late Quaternary equatorial Pacific sea surface temperature variations. Science 289, 1719-1724.

Levitus, S., 1994. World Ocean Atlas, Vol 4: Temperature. NOAA Atlas NESDIS. U.S. Govt. Printing Office.

Loutre, M.F., Berger, A., 2003. Marine Isotope Stage 11 as an analogue for the present interglacial. Glob. Planet. Change 36, 209-217.

Lyle, M.W., Prahl, F.G., Sparrow, M.A., 1992. Upwelling and productivity changes inferred from a temperature record in the central equatorial Pacific. Nature 355, 812-815.

Madureira, L.A.S., van Kreveld, S.A., Eglinton, G., Conte, M.H., Ganssen, G., van Hinte, J.E., Ottens, J.J., 1997. Late Quaternary high-resolution biomarker and other sedimentary climate proxies in a northeast Atlantic core. Paleoceanography 12, 255-269.

Marchal, O., et al., 2002. Apparent long-term cooling of the sea surface in the northeast Atlantic and Mediterranean during the Holocene. Quat. Sci. Rev. 21, 455-483.

Martinez, J.I., 1994. Late Pleistocene palaeoceanography of the Tasman Sea; implications for the dynamics of the warm pool in the Western Pacific. Palaeogeogr. Palaeoclimatol. Palaeoecol. 112, $19-62$.

Martinez, J.I., 1997. Decreasing influence of Subantarctic Mode Water north of the Tasman Front over the past 150 kyr. Palaeogeogr. Palaeoclimatol. Palaeoecol. 131, 355-364.
Martinson, D.G., Pisias, N.G., Hays, J.D., J Imbrie, J., Moore, T.C., Shackleton, N.J., 1987. Age dating and the orbital theory of the ice ages: development of a high-resolution 0 to 300,000 year chronostratigraphy. Quat. Res. 27, 1-29.

McManus, J.F., Oppo, D.W., Cullen, J.L., 1999. A 0.5-million-year record of millennial-scale climate variability in the North Atlantic. Science 283, 971-975.

Mix, A.C., Bard, E., Schneider, R., 2001. Environmental processes of the ice age: land, oceans, glaciers (EPILOG). Quat. Sci. Rev. 20, $627-657$.

Mulhearn, P.J., 1987. The Tasman Front: a study using satellite infrared imagery. J. Phys. Oceanogr. 17, 1148-1155.

Müller, P.J., Kirst, G., Ruhland, G., von Storch, I., Rosell-Melé, A., 1998. Calibration of the alkenone paleotemperature index $U_{37}^{K}$ based on core-tops from the eastern South Atlantic and the global ocean $\left(60^{\circ} \mathrm{N}-60^{\circ} \mathrm{S}\right)$. Geochim. Cosmochim. Acta 62, $1757-1772$.

Nees, S., 1997. Late Quaternary palaeoceanography of the Tasman Sea: the benthic foraminiferal view. Palaeogeogr. Palaeoclimatol. Palaeoecol. 131, 365-389.

Nelson, C.S., Hendy, C.H., Cuthbertson, A.M., 1994. Oxygen isotope evidence for climatic contrasts between Tasman Sea and Southwest Pacific Ocean during the late Quaternary. In: van der Lingen, G.J., Swanson, K.M., Muir, R.J. (Eds.), Evolution of the Tasman Sea Basin. A.A Balkema, Rotterdam, Netherlands, pp. 181-196.

Nürnberg, D., Müller, A., Schneider, R.R., 2000. Paleo-sea surface temperature calculations in the equatorial east Atlantic from $\mathrm{Mg}$ / Ca ratios in planktic foraminifera: A comparison to sea surface temperature estimates from $U_{37}^{K}$, oxygen isotopes, and foraminiferal transfer function. Paleoceanography 15, 124-134.

Pahnke, K., Zahn, R., Elderfield, H., Schulz, M., 2003. 340,000-year centennial-scale marine record of southern hemisphere climatic oscillation. Science 301, 948-952.

Passlow, V., Wang, P., Chivas, A.R., 1997. Late Quaternary palaeoceanography near Tasmania, southern Australia. Palaeogeogr. Palaeoclimatol. Palaeoecol. 131, 433-463.

Pelejero, C., Grimalt, J.O., Heilig, S., Kienast, M., Wang, L., 1999a. High resolution $U_{37}^{K}$-temperature reconstructions in the South China Sea over the last 220 kyrs. Paleoceanography 14, 224-231.

Pelejero, C., Grimalt, J.O., Sarnthein, M., Wang, L., Flores, J.A., 1999b. Molecular biomarker record of sea surface temperature and climatic change in the South China Sea during the last 140,000 years. Mar. Geol. 156, 109-121.

Pelejero, C., Calvo, E., Logan, G.A., De Deckker, P., 2003. Marine isotopic Stage 5e in the Southwest Pacific: similarities with Antarctica and ENSO inferences. Geophys. Res. Lett. 30, doi:10.1029/2003GL01819.

Petit, J.R., et al., 1999. Climate and atmospheric history of the past 420,000 years from the Vostok ice core, Antarctica. Nature 399, 429-436.

Ridgway, K.R., Dunn, J.R., 2003. Mesoscale structure of the mean East Australian Current System and its relationship with topography. Prog. Oceanogr. 56, 189-222.

Rostek, F., Ruhland, G., Bassinot, F.C., Müller, P.J., Labeyrie, L.D., Lancelot, Y., Bard, E., 1993. Reconstructing sea surface temperature and salinity using $\delta^{18} \mathrm{O}$ and alkenone records. Nature 364, 319-321.

Rostek, F., Bard, E., Beaufort, L., Sonzogni, C., Ganssen, G., 1997. Sea surface temperature and productivity records for the past $240 \mathrm{kyr}$ in the Arabian Sea. Deep-Sea Res. II 44, 1461-1480.

Rousseau, D.-D., Puissegur, J.-J., Lecolle, F., 1992. West-European terrestrial molluscs assemblages of isotopic stage 11 (Middle 
Pleistocene): climatic implications. Palaeogeogr. Palaeoclimatol. Palaeoecol 92, 15-29.

Sachs, J.P., Anderson, R.F., Lehman, S.J., 2001. Glacial surface temperatures of the southeast Atlantic Ocean. Science 293, 2077-2079.

Schneider, R.R., Müller, P.J., Ruhland, G., 1995. Late Quaternary surface circulation in the east equatorial South Atlantic: Evidence from alkenone sea surface temperatures. Paleoceanography 10, 197-219.

Schneider, R.R., Müller, P.J., Acheson, R., 1999. Atlantic alkenone sea-surface temperature records. Low versus mid latitudes and differences between hemispheres. In: Abrantes, F., Mix, A. (Eds.), Reconstructing Ocean History: A Window into the Future. Kluwer Academic/Plenum Publishers, New York, pp. 33-55.

Sicre, M.A., Ternois, Y., Paterne, M., Boireau, A., Beaufort, L., Martinez, P., Bertrand, P., 2000. Biomarker stratigraphic records over the last 150 kyrs off the NW African coast at 25 degrees $\mathrm{N}$. Org. Geochem. 31, 577-588.

Sikes, E.L., Howard, W.R., Neil, H.L., Volkman, J.K., 2002. Glacialinterglacial sea surface temperature changes across the subtropical front east of New Zealand based on alkenone unsaturation ratios and foraminiferal assemblages. Paleoceanography 17 , doi:10.1029/2001PA000640.

Stanton, B.R., 1976. Circulation and hydrology off the west coast of the South Island, New Zealand. N. Z. J. Mar. Freshw. Res. 10, 445-467.

Thiede, J., et al., 1999. FS Sonne cruise report SO 136 TASQWA (Quaternary variability of water masses in the Southern Tasman Sea and the Southern Ocean, SW Pacific Sector). GEOMAR Rep. 89.

Tilburg, C.E., Hurlburt, H.E., O'Brien, J.J., Shriver, J.F., 2001. The dynamics of the East Australian Current system: The Tasman
Front, the East Auckland Current, and the East Cape Current. J. Phys. Oceanogr. 31, 2917-2943.

Tomczak, M., Godfrey, J.S., 2003. Regional Oceanography: An Introduction. Daya Publishing House. 390 pp.

Villanueva, J., Pelejero, C., Grimalt, J.O., 1997. Clean-up procedures for the unbiassed estimation of C37-C39 alkenone sea surface temperatures and terrigenous $n$-alkane inputs in paleoceanography. J. Chromatogr. 757, 145-151.

Villanueva, J., Grimalt, J.O., Cortijo, E., Vidal, L., Labeyrie, L., 1998. Assessment of sea surface temperature variations in the Central North Atlantic using the alkenone unsaturation index $\left(U_{37}^{K}\right)$. Geochim. Cosmochim. Acta 62, 2421-2427.

Visser, K., Thunell, R., Stott, L., 2003. Magnitude and timing of temperature change in the Indo-Pacific warm pool during deglaciation. Nature 421, 152-155.

Wang, L., Sarnthein, M., Erlenkeuser, H., Grimalt, J.O., Grootes, P., Heilig, S., Ivanova, E., Kienast, M., Pelejero, C., Pflaumann, U., 1999. East Asian monsoon climate during the Late Pleistocene: High-resolution sediment records from the South China Sea. Mar. Geol. 156, 243-282.

Wessel, P., Smith, W.H.F., 1995. New Version of the Generic Mapping Tools Released. EOS Trans. AGU 76, 329.

Winograd, I.J., Landwehr, J.M., Ludwig, K.R., Coplen, T.B., Riggs, A.C., 1997. Duration and structure of the past four interglaciations. Quat. Res. 48, 141-154.

Wolff, T., Mulitza, S., Rühlemann, C., Wefer, G., 1999. Response of the tropical Atlantic thermocline to late Quaternary trade wind changes. Paleoceanography 14, 374-383. 